\title{
The relationship between spiritual, religious and personal beliefs and disordered eating psychopathology
}

\author{
Daniel Akrawi ${ }^{*}$, Shantiban Shanmugam¹, Michael Lee ${ }^{1}$, Rohit Ghosh1', Stephen Touyz², Roger Bartrop ${ }^{1}$ \\ From 2015 ANZAED Conference: Riding the Waves to Recovery \\ Surfers Paradise, Australia. 21-22 August 2015
}

\section{Objectives}

With high rates of eating disorders and disordered eating amongst female university students, new paradigms in prevention are needed. Thus, this study aims to explore the relationships between disordered eating psychopathology (DEP) and spiritual, religious and personal belief (SRPB) facets amongst female university students in Western Sydney.

\section{Design}

A cross-sectional study was conducted surveying female university students attending the University of Western Sydney (UWS). The Eating Disorder Inventory-3 (Drive for Thinness, Bulimia, Body Dissatisfaction scales) and the World Health Organisation Quality of Life - Spiritual, Religious and Personal Beliefs BREF questionnaires were used.

\section{Participants}

A total of 616 female participants from UWS were recruited through university emails, social media and community engagement across all university campuses. The participants had a mean age of 21.45 years and a mean BMI of 23.8.

\section{Results}

Students who described themselves as being more religious had lower levels of body dissatisfaction. Furthermore, all 9 SRPB facets were correlated with lower levels of DEP. However, wholeness \& integration, and to a lesser extent inner peace derived from strong SRPBs were found to best predict lower levels of DEP.

\footnotetext{
* Correspondence: 17516600@student.uws.edu.au

'University of Western Sydney, Sydney, Australia

Full list of author information is available at the end of the article
}

\section{Conclusions}

Significant associations were found between SRPBs and lower levels of DEP. These results can be used to inform health professionals, as well as religious and spiritual leaders in understanding, addressing and preventing disordered eating in Western Sydney.

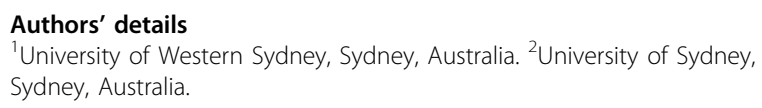

Published: 23 November 2015

doi:10.1186/2050-2974-3-S1-P3

Cite this article as: Akrawi et al:: The relationship between spiritual, religious and personal beliefs and disordered eating psychopathology. Journal of Eating Disorders 2015 3(Suppl 1):P3.
Submit your next manuscript to BioMed Central and take full advantage of:

- Convenient online submission

- Thorough peer review

- No space constraints or color figure charges

- Immediate publication on acceptance

- Inclusion in PubMed, CAS, Scopus and Google Scholar

- Research which is freely available for redistribution
C Biomed Central 